\title{
Field-scale evaluation of the chemical-biological stabilization process for the remediation of hydrocarbon-contaminated soil
}

\author{
R. H. Adams • F. J. Guzmán-Osorio • \\ V. I. Domínguez-Rodríguez
}

Received: 15 July 2012/Revised: 21 February 2013/Accepted: 1 May 2013/Published online: 30 May 2013

(C) Islamic Azad University (IAU) 2013

\begin{abstract}
Developing countries face the challenge of growing their economy while reducing the negative environmental impacts of industry, thus requiring treatment technologies that are economical and effective. One recent technology developed in the tropical part of Mexico for the remediation of petroleum-contaminated soil was tested in this scale-up project at an industrial level, whereas previously it had only been tested at laboratory scale; $150 \mathrm{~m}^{3}$ of bentonitic mud, contaminated with weathered hydrocarbons $\left(3.4^{\circ} \mathrm{API}\right)$ at $\sim 50,000 \mathrm{ppm}$, was treated with $4 \%$ $\mathrm{Ca}(\mathrm{OH})_{2}, 4 \%$ organic amendment, and a fine-root tropical grass. Hydrocarbons in soil and in leachates, as well as $\mathrm{pH}$, and acute toxicity (Microtox) were monitored for 28.8 months. At the end of the study, basal respiration, root density, and earthworm toxicity were also measured. The hydrocarbon concentration in soil was reduced to $45 \%$, and toxicity was eliminated. Hydrocarbons in leachates were reduced to $\sim 1 \mathrm{mg} / \mathrm{l}$, safe for human consumption. The $\mathrm{pH}$ adjustment depended on low soil moisture and was stabilized at 7.1. Intense revegetation resulted in good root density, within $90 \%$ of nearby uncontaminated soil under pasture. Basal respiration was increased to levels comparable to uncontaminated tropical soils with agricultural use, pasture and gallery forest. At an industrial scale, strict moisture control was necessary for good $\mathrm{pH}$ stabilization. By controlling these conditions and applying this novel treatment process, it was possible to transform a heavily
\end{abstract}

R. H. Adams ( $\square)$ · F. J. Guzmán-Osorio ·

V. I. Domínguez-Rodríguez

Remediation Laboratory, Academic Division of Biological

Sciences (DACBiol.), Universidad Juárez Autónoma

de Tabasco, Km 0.5 Carretera VHSA-Cárdenas,

CP 86150 Villahermosa, Tabasco, Mexico

e-mail: drrandocan@hotmail.com contaminated geological material into a non-toxic, fertile, soil-like substrate capable of maintaining a complete vegetative cover and microbial activity comparable to similar soils in a tropical environment.

Keywords Appropriate technology · Leachates · Restoration - Total petroleum hydrocarbons - Tropics . Vegetative cover

\section{Introduction}

The demand for petroleum derivatives, especially for fuel, lubricants, and chemical feedstocks, has increased dramatically in the last 50 years. To supply these demands, petroleum has been explored for, produced, and refined in many countries. In some areas, especially in developing economies, the demand for these resources, for national or regional uses, has also increased. Nearly one-fourth of all petroleum production world wide occurs in tropical and semitropical areas, including Southeast Asia (Indonesia, Malaysia, Vietnam, Thailand), Mexico, northern South America (Venezuela, Colombia, Ecuador, Peru), Brazil, western Africa (Nigeria and Angola, principally), and also Northeast India (Assam) and southern China (Guangdong). Likewise, semitropical areas in the United States, notably southeast Texas and southern Louisiana, are major producers of oil and gas (EIA 2009). Moreover, the major petroleum producing countries in the Middle East, Iran, Iraq, and Saudi Arabia (Bakhtiari 2003) are also in subtropical regions. This demand has not been without its attendant environmental consequences, land contamination, and deterioration being common. This is principally associated with inadequate measures in the production, transportation, and refining of crude oil. This issue is more 
severe in the developing countries where there were no effective regulatory policies on the environment (Escalante Espinosa 2000; Infante 2001; Yazdanparast et al. 2004; Osuji and Ezebuiro 2006; Torres et al. 2007; Sakari et al. 2010; Abdulsalam et al. 2011).

There are several remediation techniques that have proven to be an excellent option for remediation purposes (Torres et al. 2007). But in many of these regions, especially in developing economies, there is a need for low cost, easily implemented technologies to remediate areas that are impacted due to accidental spills and inadequate waste treatment procedures. In part, this is because the physicochemical technologies have their limitations. They are more expensive to implement at full scale, they are frequently not environmentally friendly, their technologies are complex, and they may lead to destruction of soil texture and fertility characteristics (Abdulsalam et al. 2011), compared to bioremediation processes which are gaining ground due to their simplicity, higher efficiency, and cost-effectiveness (Yousefi Kebria et al. 2009). One such technology was developed at the turn of the twentyfirst century in the Gulf of Mexico region, which uses simple methods and locally available materials, machinery, and know-how, thereby greatly increasing ease of implementation, and reducing costs (Adams 2004a, 2008). This method, called the chemical-biological stabilization process, was developed based on empirical observations of personnel in the state-run petroleum company, Petróleos Mexicanos (PEMEX), followed by systematic experimentation with respect to reagent order, dosing, and organic amendment type (Adams 2004a, b; Adams et al. 2007; Mayo-López et al. 2010). It has also been compared with other, similar technologies and found to be as effective or more so in reducing toxicity and promoting revegetation (Adams and Guzmán-Osorio 2008). Furthermore, due to the simplified treatment process, the cost of this method is approximately $45 \%$ less than conventional land farm bioremediation (Adams and Guzmán-Osorio 2008). It can be used to treat drilling cuttings (Adams 2004a), high concentrations $(5-11 \%)$ of very weathered hydrocarbons (Adams et al. 2005; Adams and Guzmán-Osorio 2008) and marshy soil co-contaminated with saline process water (Adams et al. 2005).

Previously, these experiments were carried out at a laboratory scale $(\sim 20 \mathrm{~kg})$ to determine proof of process. Compared to the prior investigations (Adams 2004a, b; Adams et al. 2007; Adams and Guzmán-Osorio 2008), the aims of this study were (1) conduct a field-scale test to evaluate implementation at a larger, industrial scale and (2) to determine how operating variables may affect performance in the long term. This research was carried out and monitored for nearly 3 years, between October 2007 and March 2010 in Cosoleacaque, Veracruz, Mexico.

\section{Materials and methods}

\section{Site background}

The site from which the contaminated material was collected was a previous sulfur mine in southern Veracruz State, Mexico, which used the Frasch process to extract this mineral from near surface salt domes (wells approximately 80-200 $\mathrm{m}$ deep). In the industrial process, the extracted material was treated with sulfuric acid to "mineralize" and separate the petroleum and solids from the raw sulfur. The resulting petroleum, acidic wastewater, and bentonite claybased drilling fluids were deposited into a large (320 ha) holding dam in which a sediment "beach" of approximately 23 ha formed at the mouth of the effluent discharge (geographic coordinates $17^{\circ} 52.441^{\prime} \mathrm{N}, 94^{\circ} 44.985^{\prime} \mathrm{W}$ ). In the mid-1990s, the mine was closed and transferred to the Mexican Government with PEMEX, taking charge of the cleanup. The holding dam was neutralized with magnesium oxide but the sediment beach still requires treatment, containing approximately 5-7\% (on average) of very weathered hydrocarbons.

\section{Characteristics of the material treated (initial)}

The material that was treated was from geologic origin, mainly composed by drilling fluids and cuttings contaminated with weathered petroleum and mixed with sandy backfill. Prior to treatment, the contaminated sediment was characterized to determine its properties. Total petroleum hydrocarbons (TPH) were determined by EPA method 418.1 (EPA 1997) using perchloroethylene as an extraction solvent (Adams and Guzmán-Osorio 2008). The contaminated material was found to contain nearly $5 \% \mathrm{TPH}$. The free-phase product from the site was also characterized for API gravity using a dilution-extrapolation hydrometer procedure (Adams et al. 2011) and found to have $3.4^{\circ} \mathrm{API}$. The hydrocarbon groups were fractionated by a differential solvent column separation similar to that used by Salanitro et al. (1997), as modified by Escalante Espinosa (2000), using hexane-toluene $(1: 1)$ to elute the saturates, toluenemethanol (1:1) for the aromatics, and methanol-acetone (1:1) for the polars + resins. The free product from the oily crust was found to have $30.1 \%$ asphaltenes, $19.7 \%$ polars + resins, and $20.6 \%$ and $29.6 \%$ of aromatics and aliphatics, respectively. The hexane soluble faction (not including asphaltenes) of this free product was also analyzed by gas chromatography according to Mexican norm NOM-138-SEMARNAT-2003 (EPA 8015 equivalent; SEMARNAT 2005). The chromatograph showed an unresolved mixture lacking salient peaks, typical of very weathered hydrocarbons rich in branched and cyclic alkanes and condensed aromatic ring structures between 
the range of $\mathrm{C}_{10}-\mathrm{C}_{28}$. Texture was determined according to Mexican norm NOM-021-SEMARNAT-2000 (SEMARNAT 2002) and found to contain $70 \%$ fines (clay and fine silt). The initial $\mathrm{pH}$ and electrical conductivity were 6.8 and $0.004(\mathrm{dS} / \mathrm{m})$, respectively.

\section{Treatment cell preparation}

For this field-scale evaluation, contaminated material was excavated from the sediment beach in the holding dam, and transported to a different, industrial center provided by an industry partner for collaborative investigation, CEISA de C.V. This Center for Treatment of Industrial Wastes is located $23.5 \mathrm{~km}$ from the extraction site, at geographic coordinates $18^{\circ} 1.393^{\prime} \mathrm{N}, 94^{\circ} 35.585^{\prime} \mathrm{W}$. At the contaminated site, permission has been obtained from government authorities for in situ surface treatment of the material in the sediment beach. This was justified in a previous site characterization demonstrating low hydrocarbon infiltration into the clayey subsoil and lack of aquifer contamination. However, at the treatment center, it is was deemed prudent to use a plastic liner, since there was no previous study of subsoil conditions and potential groundwater contamination.

For this experiment, a land farm-type treatment cell was prepared at the treatment center. The treatment cell had dimensions of approximately $15-25 \mathrm{~m}$, with a $1 \%$ grade, 1.2 -m-high earthen berm, and a $0.76-\mathrm{mm}$ (30 mil) highdensity polyethylene (HDPE) liner, (thermally sealed). On top of the liner, $10 \mathrm{~cm}$ of sand was placed to increase drainage, which flowed into a recollection pond of $7 \mathrm{~m} \times 2 \mathrm{~m} \times 1.5 \mathrm{~m}$ deep. Initially, the sediment was saturated with water, and once, during the early stage of treatment, it was necessary to recover the leachate, which had a thin film of oil, with a vacuum truck and treat it in an oil-water separator.

Contaminated sediment $\left(150 \mathrm{~m}^{3}\right)$ from the sulfur mine was extracted from the site with an excavator, and transported and placed in the treatment cell to a depth of $\sim 60 \mathrm{~cm}$. After 6 months, this material had settled to a depth of $\sim 50 \mathrm{~cm}$.

\section{Chemical-biological stabilization treatment}

During the early stages of treatment, the material was essentially saturated with water, due to its location in a low-lying area prior to excavation. To reduce the moisture content, the material was placed into two windrows $\sim 1.8 \mathrm{~m}$ high to drain for about 10 days. It was then processed using 4 (w/w, dry wt. basis) of hydrated lime $\left(\mathrm{Ca}(\mathrm{OH})_{2}\right)$ which was applied manually and incorporated by mixing four times with an excavator. Due to the continued high moisture content of the material, it was placed into four smaller windrows, about $1.2 \mathrm{~m}$ high, to drain for 1 week. Subsequently, the material was leveled out and $4 \%$ (w/w, dry wt. basis) of fresh sugarcane filtrate cake (cachasse) was applied on top and incorporated with an excavator, mixing four times. After mixing, the material was extended over the treatment cell. About 2 weeks later, during monitoring, it was determined that the cachasse was probably not sufficiently homogenized and an additional mixing (four times) was applied. The sugarcane cachasse was added as an organic conditioner to absorb free organic contaminants in the material, improve the field capacity, structure, and reduce soil leachates. Also, to stimulate microbial-induced transformations (mineralization and humification) of contaminants to form which are less toxic or less mobile in the environment (Adams 2004a, b; MayoLópez et al. 2010). The material was extended and monitored for $\mathrm{pH}$. After the $\mathrm{pH}$ had dropped to roughly eight (a tolerable range), humidicola grass (Brachiaria humidicola) was planted to establish a vegetative cover, avoid erosion, and to better soil structure and general nutrition. The grass was applied by seed at $1 \mathrm{~g} / \mathrm{m}^{2}$ (equivalent to $10 \mathrm{~kg} / \mathrm{ha}$ ) slightly pressing the seed into the soil by walking over the treated material. Two weeks after planting, the material was irrigated once with $10 \mathrm{~m}^{3}$ of untreated ground water, manually with a pressure sprayer. This treatment was carried out for almost 3 years in a tropical monsoon climate similar to that described by Adams Schroeder et al. (2002) but with greater evaporation potential due to the northern and southern winds in the Isthmus of Tehuantepec. Average temperatures are slightly less (approximately $26^{\circ} \mathrm{C}$ ), especially during the "northerns" season; precipitation is slightly more frequent but somewhat less abundant (1,500-2,000 mm).

\section{Sampling and monitoring}

The protocol recommended for sampling equatorial soils by Osorio and Casamitjana (2011) was used. The treatment cell was monitored by collecting discrete samples from 12 equally spaced points. These were collected using a $54 \mathrm{~cm}$ long, $10 \mathrm{~cm}$ diameter split spoon, stainless steel sampler, obtaining material from the surface down to the sand leachate layer, but trying not to include the sand layer. The discrete samples were combined to make a composite sample, and the composite sample was divided into four subsamples (pseudo-repetitions) and stored in sealed plastic bags in refrigeration $\left(4{ }^{\circ} \mathrm{C}\right)$ until analyzed for the following parameters.

\section{Hydrocarbon concentration}

Total petroleum hydrocarbon (TPH) concentration was determined using EPA method 418.1 (EPA 1997) with 
perchloroethylene as the extraction and measurement solvent (Adams and Guzmán-Osorio 2008). A silica gel cleanup of extracts was also employed to remove nonpetroleum organic materials. Free-phase product from the site was used to prepare a calibration curve. When necessary, sample extracts were diluted with the same solvent to obtain reliable infrared measurements in an InfraCal TPH spectrophotometer (Wilks Enterprise, South Norwalk, Connecticut, USA).

\section{$\mathrm{pH}$}

During the early period of treatment, immediately following the incorporation of the cachasse, spot checks were made in the field using disposable $\mathrm{pH}$ strips and later confirmed in the laboratory. All subsequent (as well as initial) $\mathrm{pH}$ determinations were made in the laboratory using 1:2.5 proportions of soil to deionized water and a $\mathrm{pH}$ electrode as per Mexican norm NOM-021-SEMARNAT2000.

\section{Hydrocarbons in leachates}

Toxic characteristic leaching procedure (TCLP) leachates were prepared with an acetic acid extract $(\mathrm{pH} \sim 5)$ as per Mexican norm NOM-053-SEMARNAT-1993 (SEMARNAT 1993) using an orbital shaker at 200 RPM for mixing. The filtered extract was analyzed for total petroleum hydrocarbons by method EPA 418.1 as described previously.

\section{Reference site selection criteria}

At the end of this study (28.8 months), it was necessary to select a reference site near the site where the contaminated material was collected, to assess the biological indicators and soil fertility recovery of the treated material. The reference site was selected with the following criteria in mind: the closest uncontaminated site with soil properties and soil use as similar to the contaminated site as possible. The selected reference site is $2.84 \mathrm{~km}$ from the contaminated site (geographic coordinates $17^{\circ} 52.539^{\prime} \mathrm{N}, 94^{\circ} 46.765^{\prime} \mathrm{W}$ ), and both are located in low-lying, seasonally floodable areas. In the contaminated site, the material was rich in smectite clay, from the bentonite used in the drilling fluids deposited in the holding dam. In the reference site, there is also an abundance of smectite clays as evidenced by the gilgai microrelief observed during the dry season (vertic properties, IUSS 2006). Nonetheless, there may be some conceptual limitations when comparing between the reference site and treated material since the reference site is a natural soil, and the treated material is a geological substrate of anthropomorphic origin. In the reference site, like in the contaminated site, the predominant soil use is for pasture (bovine cattle). The site was delimited in an area of $15 \times 25 \mathrm{~m}$, and four samples were taken to a depth of 30 and $20 \mathrm{~cm}$ in diameter as per Osorio and Casamitjana (2011). Similarly, sampling was performed in the treatment cell. Both samples were analyzed for the following parameters:

\section{Acute toxicity}

Toxicity was monitored at the beginning and throughout the study by the Microtox bioassay. The assay is based on the analysis of light emission reduction in luminescent bacteria (Vibrio fischeri) under toxic stress and provides a measure of sublethal response. The analysis was carried out on a Microbics model 500 analyzer (Microbics Corp.; Carlsbad, California), testing luminescence inhibition after $15 \mathrm{~min}$ exposure to filtered dilutions of the soil in deionized water (1/10), based on the method in the Mexican norm NMX-AA-112-1995-SCFI (SECOFI 1996). A dose-response curve was generated, and the $\mathrm{EC}_{50}$ (effective concentration 50, concentration of sample which reduces the bioluminescence $50 \%$ ) was calculated. From this $\mathrm{EC}_{50}$ value, the toxicity was also calculated in toxicity units (TU), using the relationship: $\mathrm{TU}=(1 /$ $\mathrm{EC}_{50}$ ). This analysis was run on four pseudo-replicates collected as described in the section on sampling and monitoring.

\section{Subchronic toxicity}

At the end of this study, toxicity was also determined with an earthworm bioassay (Eisenia foetida) as per Neuhauser et al. (1985). The method is based on toxicity assessment by contact (through the exterior mucosal membrane) or by ingestion of contaminated soil particles. Ten organisms were used per test vessels, and five replicates were performed for each sample. Soils (contaminated and reference) were placed into the containers and wetted (35-40\% field capacity). Mortality and weight loss were determined. Counting was performed at 7, 14, 21, and 28 days of exposure.

\section{Root density}

Soil samples with a known volume $(20 \mathrm{~cm}$ diameter, $30 \mathrm{~cm}$ deep) were used for this determination. To separate the roots, the soil was gradually mixed with water and the roots were floated out and rinsed, then screened using a 0.6-mm steel filter. The rinsed material was dried in an oven at $60{ }^{\circ} \mathrm{C}$ and weighed on a balance. The root biomass was calculated in terms of dry weight per area. 


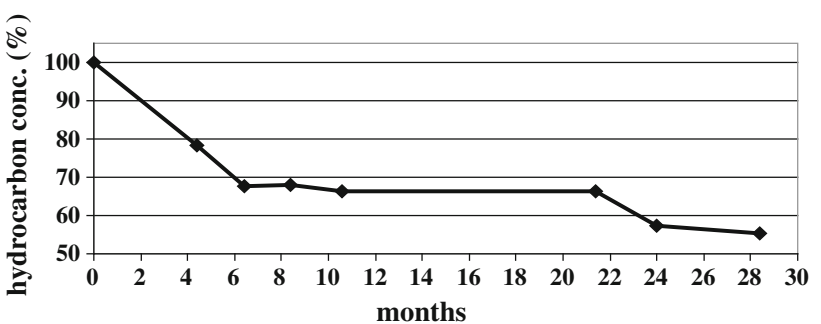

Fig. 1 Total petroleum hydrocarbon degradation during treatment

Basal respiration

Microbial respiration was determined in static tests run at $30{ }^{\circ} \mathrm{C}$ in sealed jars using $\mathrm{NaOH}$ as a carbon dioxide trap and later titrating with phenolphthalene solution (1 in $96 \%$ ethanol) to neutrality, as described by Mayo-López et al. (2010).

\section{Results and discussion}

Hydrocarbon biodegradation

The results of hydrocarbon degradation are shown in Fig. 1. In this figure, the range in the y-axis is shown starting at $50 \%$ to reflect only the potentially biodegradable fractions (not including asphaltenes and polars + resins). From this graph, it can be observed that during the first 6 months, there was an important decrease $(32.3 \%)$ in hydrocarbon concentration. Following this initial biodegradation period, there was very little if any reduction in the hydrocarbon concentration for nearly 16 months. Afterward, there was a second significant period of biodegradation for about 6 months.

The relatively large reduction in the concentration that occurred during the first 6 months of treatment was likely due to biodegradation of the fraction of hydrocarbons which are both bioavailable and easily mineralized due to their chemical structure (such as alkanes with little or no branching). Further degradation was null or very slow for the next 15 months, but after 21 months, another period of degradation also occurred, for 6-7 months. This second period probably corresponds to the humification of the more recalcitrant hydrocarbon fraction. The overall reduction during this period was $45 \%$, which is considerable when the recalcitrant nature of the starting mix of hydrocarbons is taken into account $(49.8 \%$ asphaltenes and polars + resins; $3.4^{\circ} \mathrm{API}$ ).

This second period (after 21 months) in overall hydrocarbon reduction is also reflected in the concentration of hydrocarbons in TCLP leachates, these being linearly correlated $\left(R^{2}=0.998\right)$ with the hydrocarbon concentration in
Table 1 Total petroleum hydrocarbon concentration in TCLP leachates

\begin{tabular}{ll}
\hline Months & $\begin{array}{l}\text { Hydrocarbon } \\
\text { concentration }(\mathrm{mg} / \mathrm{l})\end{array}$ \\
\hline 4.4 & 4.07 \\
6.5 & 1.34 \\
8.5 & 3.11 \\
10.7 & 2.44 \\
21.7 & 2.15 \\
24.3 & 1.33 \\
28.8 & 1.19 \\
\hline
\end{tabular}

soil. This correlation suggests that, at least during the final months of treatment, the hydrocarbon biodegradation resulted in a reduction in availability, which would be consistent with humification processes.

Hydrocarbons in leachates

The concentration of hydrocarbon in leachates is shown in Table 1. The determination of the initial leachate concentration was complicated due to the presence of undissolved free product (a thin sheen of hydrocarbons) which was not recovered during the filtration process. As seen in this table, there was a general tendency to reduce the concentration of hydrocarbons in the leachates over time. The final value after 28.8 months was very nearly $1 \mathrm{mg} / \mathrm{l}$, which is considered an acceptable limit to assure that groundwater does not present unpleasant odors or flavors, and that it is suitable for human consumption (WSDE 1991). Between the period of 4.4-6.5 months, there was a marked decrease in leachable hydrocarbon concentration that later rose after 8.5 months. This intermediate reduction and following increase may be related to the absorption of some of the hydrocarbons into the organic amendment added ( $4 \%$ cachasse) and subsequent liberation due to the decomposition of the organic fibers. Adams (2004a) and Adams and Guzmán-Osorio (2008) observed similar trends for test run at smaller scales.

\section{$\mathrm{pH}$}

The initial $\mathrm{pH}$ of the material to be treated was 6.8. During the treatment with calcium hydroxide, the $\mathrm{pH}$ rose markedly and was only partially neutralized by the addition of the organic amendment. Three weeks after the cachasse was added, spot tests were conducted in different parts of the treatment cell. At that time, $\mathrm{pH}$ was also determined in the leachates coming from the effluent tube into the leachate recollection pond and was still found to be relatively high (9.45). The $\mathrm{pH}$ in different parts of the treatment cell ranged from 8.69 to 9.14 and was deemed too high to initiate planting. Also, in the lower sections of the 
treatment cell, very high humidity was encountered (greater than $80 \%$ of field capacity). A little over 2 weeks later, when more of the moisture had drained from the cell and there were very few areas with overly high moisture content, the $\mathrm{pH}$ was found to be more reasonable $(\sim 8.2)$ and considered sufficiently low for planting. Following this initial period of $\mathrm{pH}$ adjustment, only slight variations in $\mathrm{pH}$ near neutrality (6.3-7.6) were observed, with the final $\mathrm{pH}$ after 28.8 months being 7.1 .

During the initial period, it appears that the reduction in the $\mathrm{pH}$ was dependent on the drainage in the treatment cell. Only after the material had drained sufficiently did the $\mathrm{pH}$ drop into an adequate level for planting. This is consistent with a biological mechanism for $\mathrm{pH}$ modification corresponding to fermentation reactions during the initial period of high moisture, resulting in the formation of alcohols, and the subsequent oxidation of these compounds into organic acids during a more aerobic phase. Adams (2004a) also observed a delayed period for $\mathrm{pH}$ adjustment when other very clayey materials (bentonite clay-based drilling cuttings) were remediated in medium-scale treatment cells $\left(0.6 \mathrm{~m}^{3}, 40 \mathrm{~cm}\right.$ deep $)$. Furthermore, the $\mathrm{pH}$ adjustment in that study was much faster in materials with easily degradable carbon substrates (sugarcane cachasse) than with less degradable substrates (partially composted cacao husks), and when saw dust was used as an organic amendment, the $\mathrm{pH}$ adjustment was very poor (only down to $\mathrm{pH} 10$ after 8 months of treatment). With smaller cells (20 kg, $20 \mathrm{~cm}$ deep) Adams and Guzmán-Osorio (2008) did not observe this delay, possibly due to the rapid drainage, aerobic conditions and the corresponding production of organic acids. In the studies in small treatment cells, the $\mathrm{pH}$ adjustment generally occurs in less than 1 week.

\section{Acute toxicity}

The average initial toxicity using the Vibrio fischerii (Microtox) bioassay was $10.5 \mathrm{TU}$. When referenced to the background toxicity for this site (7.43 TU), and normalizing using the quarter log scale proposed by Kross and Cherryholmes (1993), this initial value was considered to be in the slightly toxic range (8.37-12.16 TU). After 4.4 months, the toxicity in all samples was reduced to or below background levels and stayed at this level during the remainder of the study.

The average value in the Microtox bioassays at the start of the study was considered slightly toxic, when compared to the background level. However, this may be somewhat misleading. Of the four samples tested, three were below background and one was at the high end of the toxic range, 19.7 TU (toxic range, 12.16-19.89 TU). This indicates that the material was generally of low toxicity but may have had some "hot spots" were the toxicity was much higher. However, it appears that these hot spots were detoxified during the treatment. After a little over 4 months, all of the samples tested were at or below background toxicity levels. This is also consistent with the earthworm bioassay done at the end of treatment (nearly 29 months).

\section{Subchronic toxicity}

At the end of the monitoring period (28.8 months), the treated material was tested using the Eisenia foetida (earthworm) bioassay and compared to an uncontaminated reference area in a low-lying floodable pasture near the site where the contaminated material was excavated. The results of the bioassay (mortality and weight loss) are shown in Table 2. In these tests, no significant difference $(P<0.95)$ was found either in mortality or in final biomass between the treated soil and the reference soil. Furthermore, the standard deviation in the weights in these tests was very low ( $<2 \%$ of the average values).

\section{Root density and basal respiration}

The basal respiration rate and root density data are presented in Figs. 2, 3 and 4. In this study, a range of root biomass values were observed in both the treatment cell (0.71-1.65 ton/ha) and the reference area (0.73-2.54 ton/ ha), typical of the heterogeneity that one would expect from field data. The root biomass values in the treatment

Table 2 Earthworm bioassay results in treatment material and soil reference site

\begin{tabular}{lllll}
\hline Site & $\begin{array}{l}\text { Average } \\
\text { mortality } \\
(\%)\end{array}$ & $\begin{array}{l}\text { SD } \\
\text { mortality }\end{array}$ & $\begin{array}{l}\text { Average } \\
\text { weight loss } \\
(\%)\end{array}$ & $\begin{array}{l}\text { SD } \\
\text { weight } \\
\text { loss }\end{array}$ \\
\hline $\begin{array}{l}\text { Treated } \\
\text { material }\end{array}$ & 1.5 & 1.9 & 50.25 & 0.11 \\
\begin{tabular}{l} 
Reference site \\
\hline
\end{tabular} & 0 & 0 & 50.75 & 0.31 \\
\hline
\end{tabular}

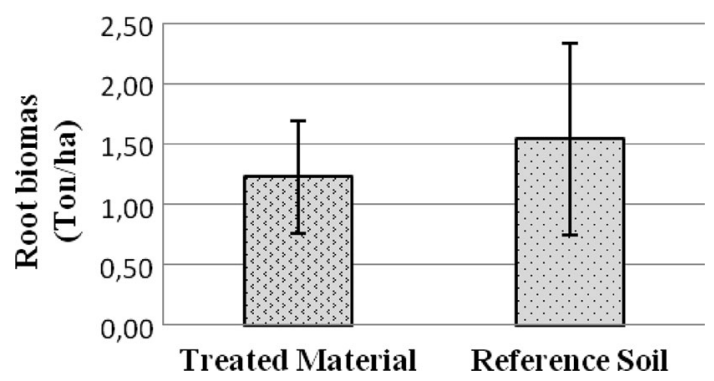

Fig. 2 Statistical comparison of root biomass between the treatment cell and the reference area. Error bars represent $95 \%$ confidence intervals (mean difference) 


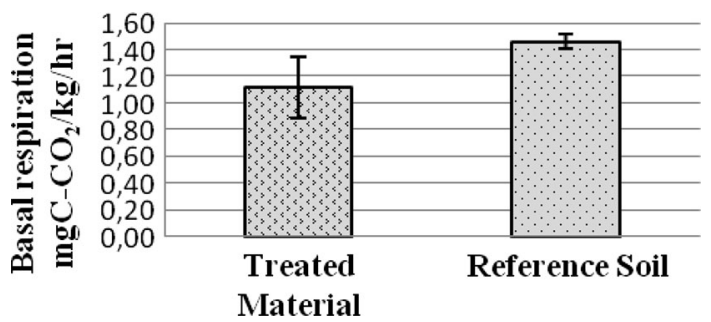

Fig. 3 Statistical comparison of basal respiration between the treatment cell and the reference area. Error bars represent $95 \%$ confidence intervals (mean difference)

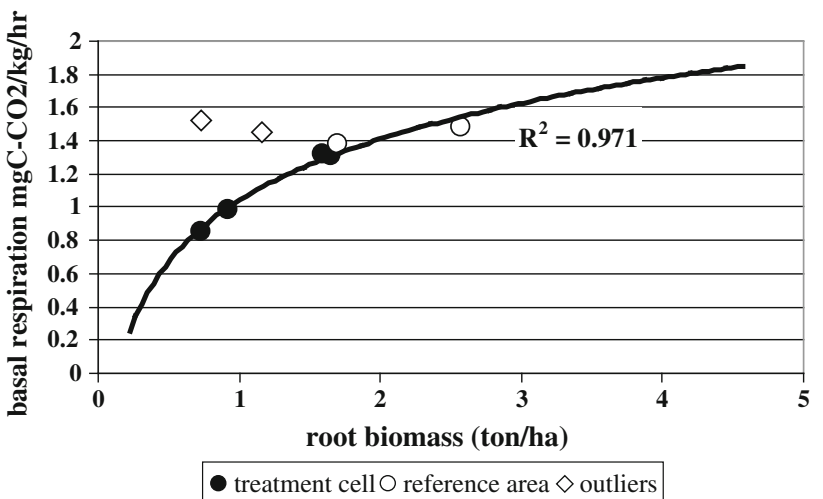

Fig. 4 Relationship between root density and basal respiration in treatment cell and reference soil

cell were within the same range as those from the reference area, although one sampling point in the reference area was considerably higher than all others (from both the reference area and the treatment cell). Nonetheless, there was no significant difference $(P<0.95)$ in root biomass between the treatment cell and the reference area (Fig. 2).

In the treatment cell, the respiration was directly proportional to the root biomass $\left(R^{2}=0.971\right)$. However, in the reference area, two samples did not follow this trend (outliers). In these samples, the root biomass was lower, even though the respiration rate remained high. Nonetheless, the respiration rate in the treatment cell was within $90 \%$ of that in the reference area in half of the sampling points. Statistics data show significant difference $(P>0.95)$ in respiration between the treated material and the reference area, but there was no obvious difference in plant growth (Fig. 3).

In Table 3, a summary of biological indicators with respect to chemical parameters is shown. As seen in this table, a reduction in overall TPH concentration and hydrocarbons in leachates reduced acute toxicity to below background levels and allowed for earthworm and root activity in a range comparable to the uncontaminated reference site.

The proportional relationship between root biomass and basal respiration observed in this study $\left(R^{2}=0.971\right)$, was also found by Wang et al. (2007), in an experiment on the contribution of roots to soil respiration and the carbon balance. Although this trend was not found in the reference area (two samples had high respiration rates even though root biomass was relatively low), it is possible that this was due to recent defecation or urination by cattle in the area, resulting in a more favorable $\mathrm{C}: \mathrm{N}$ ratio, and therefore greater respiration. Bilotta et al. (2007) observed similar results on intensively managed pastures, in which animal feces increased the basal respiration rate.

When these two outliers are removed from the data set, the combined data (treatment cell and reference soil) show increasing respiration as a logarithmic function $\left(R^{2}=\right.$ 0.971) of root biomass with a leveling off tendency at higher biomass concentrations (Fig. 4). It would be expected that with time the overall root biomass and microbial respiration in the treated material would continue to increase to levels equivalent to that found in the reference area, depending on land management practices. Two

Table 3 Comparison of biological indicators and chemical parameters

\begin{tabular}{|c|c|c|c|c|c|c|c|c|}
\hline \multirow[t]{3}{*}{ Treatment } & \multicolumn{8}{|l|}{ Analysis } \\
\hline & \multirow{2}{*}{$\begin{array}{l}\text { TPH } \\
(\mathrm{mg} / \mathrm{kg})\end{array}$} & \multirow{2}{*}{$\begin{array}{l}\text { Leachates } \\
(\mathrm{mg} / \mathrm{l})\end{array}$} & \multirow{2}{*}{$\begin{array}{l}\mathrm{pH} \mathrm{H}_{2} \mathrm{O} \\
(2: 1)\end{array}$} & \multirow{2}{*}{$\begin{array}{l}\text { Microtox } \\
\text { (UT) }\end{array}$} & \multicolumn{2}{|c|}{ Earthworm bioassay } & \multirow{2}{*}{$\begin{array}{l}\text { Root density } \\
\text { (Ton/ha) }\end{array}$} & \multirow{2}{*}{$\begin{array}{l}\text { Basal respiration } \\
\left(\mathrm{mg}_{\mathrm{C}-\mathrm{CO} 2 / \mathrm{kg} / \mathrm{h}}\right)\end{array}$} \\
\hline & & & & & $\begin{array}{l}\text { Mortality } \\
(\%)\end{array}$ & $\begin{array}{l}\text { Weight loss } \\
(\%)\end{array}$ & & \\
\hline Contaminated material & $48,123 *$ & $4.07 *$ & 6.8 & 10.5 & $\mathrm{ND}^{\mathrm{a}}$ & $\mathrm{ND}^{\mathrm{a}}$ & $\mathrm{ND}^{\mathrm{a}}$ & $\mathrm{ND}^{\mathrm{a}}$ \\
\hline Treated material & $26,574^{*}$ & $1.19^{*}$ & 7.1 & 7.4 & 1.5 & 50.25 & 1.22 & $1.12 *$ \\
\hline Reference site & $\mathrm{ND}^{\mathrm{b}}$ & $\mathrm{ND}^{\mathrm{b}}$ & $\mathrm{ND}^{\mathrm{b}}$ & $\mathrm{ND}^{\mathrm{b}}$ & 0 & 50.75 & 1.54 & $1.46^{*}$ \\
\hline
\end{tabular}

$N D$ not determined

* Statistically significant (confidence interval $=95 \%, P<0.05$ )

a Initial conditions not suitable for root production or aerobic microbial activity (respiration)

b No record/history of contamination $(\sim 0 \mathrm{mg} / \mathrm{kg})$ 
Table 4 Basal respiration in treated material and other tropical soils

${ }^{\text {a }}$ In $\mathrm{mgC}-\mathrm{CO}_{2} / \mathrm{kg} / \mathrm{h}$

b Calculated based on a soil depth of $30 \mathrm{~cm}$, and $\rho=1.3 \mathrm{~g} /$ $\mathrm{cm}^{3}$

\begin{tabular}{|c|c|c|c|}
\hline Soil type & Respiration rate ${ }^{\mathrm{a}}$ & Soil origin & Reference \\
\hline $\begin{array}{l}\text { Chemical-biological } \\
\text { stabilization treatment cell }\end{array}$ & $0.9-1.3$ & Veracruz, Mexico & This study \\
\hline $\begin{array}{l}\text { Floodable pasture (reference } \\
\text { area) }\end{array}$ & $1.4-1.5$ & Veracruz, Mexico & This study \\
\hline Alluvial soil—cacao/sugarcane & $0.9-1.0$ & Tabasco, Mexico & Adams Schroeder et al. (2002) \\
\hline Savannah with pasture & $0.3-1.0$ & Venezuela & Gómez and Paolini (2006) \\
\hline Gallery forest & $0.8-1.5$ & Costa Rica & Schulze $(1967)^{\mathrm{b}}$ \\
\hline Savannah-forest mosaic & 1.9 & Venezuela & Sánchez et al. (2005) \\
\hline Sandy coastal soil—coconut & 1.1 & Tabasco, Mexico & Adams Schroeder et al. (2002) \\
\hline Gallery forest & 0.6 & Venezuela & Sánchez et al. (2005) \\
\hline
\end{tabular}

of the four samples tested were already within $90 \%$ of this reference level for respiration.

In Table 4, a comparison is made for the basal respiration found in the treated material and other soils from tropical environments. The material in the treatment cell had similar respiration rates as other soils in a tropical environment, being in the same range as rich alluvial soils under cultivation (Adams Schroeder et al. 2002), savannah with pasture (Gómez and Paolini 2006) and gallery forest (Schulze 1967). This is especially noteworthy considering that the contaminated material was not a soil, but a geological material (drilling muds with cuttings, plus some sandy fill). Nonetheless, during the treatment process, it was transformed into a soil-like material capable of sustaining a good basal respiration (microbial activity) and a root density similar to the reference area (Fig. 5).
Fig. 5 Conditions of initial and treated material. a Excavation and collection of contaminated material from the sediment beach of the holding dam. b Growth of pasture during the second rainy season in the treatment cell
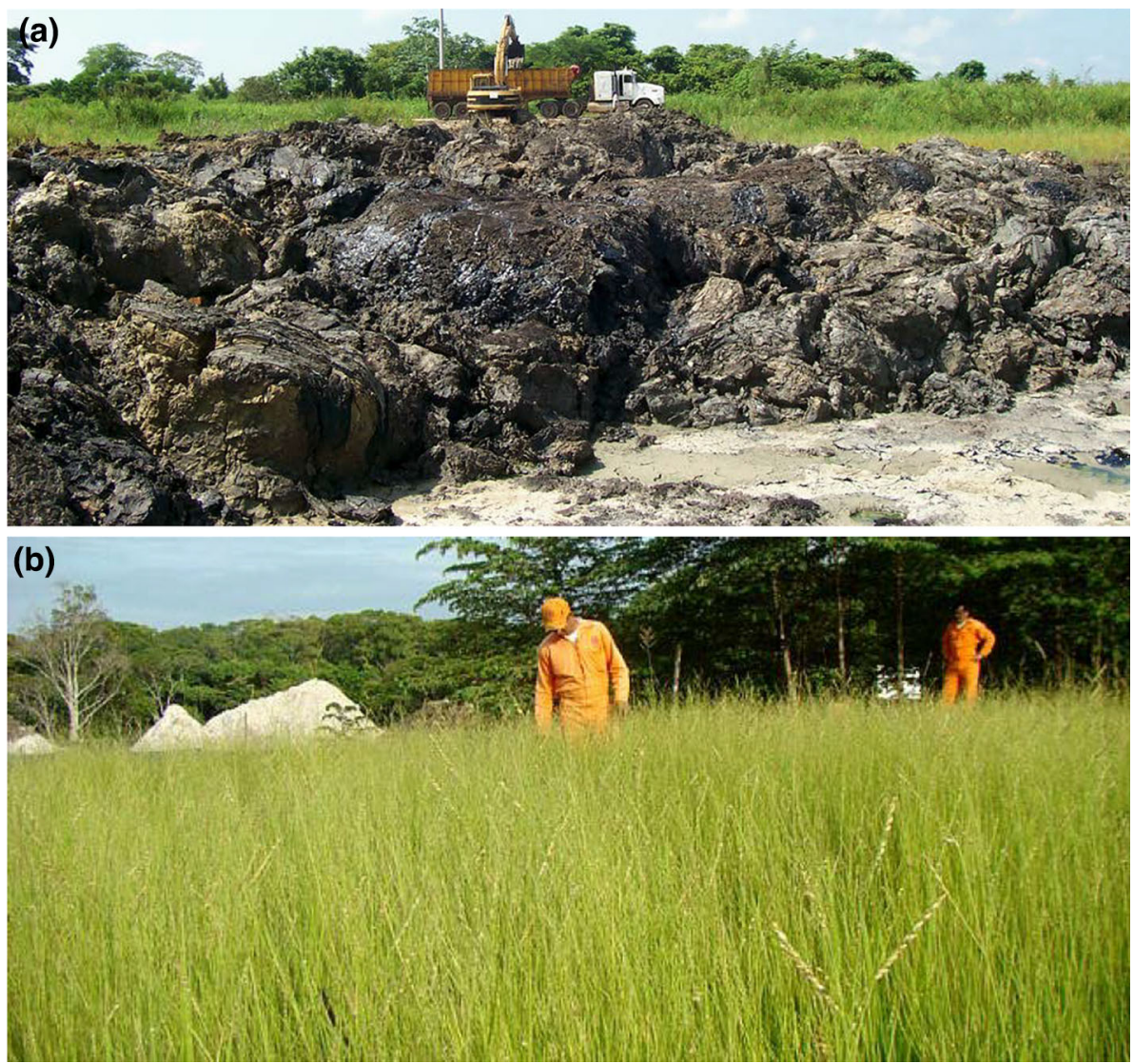


\section{Conclusion}

In this study, a novel remediation process was tested at a full industrial scale, during which important observations were made with respect to material handling which were not evident in studies conducted at smaller scales. Particularly important was the finding with respect to the relationship between (biological) $\mathrm{pH}$ adjustment and moisture management. In future, full-scale projects will be especially important to construct the treatment cells to optimize drainage using greater elevation gradients and more uniform grading. It was also shown that leachates in the treated material were reduced to low levels. Furthermore, biological indicators (toxicity, basal respiration, root density) all indicate a good activity and the transformation of a contaminated geological material into a fertile, soil-like substrate capable of maintaining a complete vegetative cover and microbial activity comparable to similar soils in a tropical environment.

Acknowledgments This study is part of a research project entitled "Industrial Scale-up of the Chemical-Biological Stabilization Process for Contaminated Soils from the Agua de Mina Sediment Beach in the Texistepec Mining Unit, Municipality of Texistepec, Vercruz" funded jointly by the Remediation Laboratory of the Academic Division of Biological Sciences (Universidad Juárez Autónoma de Tabasco) and an industrial partner, Comunicaciones y Electrónica Industrial S.A. de C.V. (CEISA); Grant No. UJAT-CEISA 010507/ POA20070751. We are grateful to Mr. Oscar Domingo Danglada Alarcón of CEISA for co-sponsoring this research and also to $\mathrm{Mr}$. Héctor López Guerrero and Mr. Juan Avila Gonzales (both from Pemex Gas y Petroquímica Básica) for their assistance with access to the Mining Unit to obtain material for treatment.

\section{References}

Abdulsalam S, Bugaje IM, Adefila SS, Ibrahim S (2011) Comparison of biostimulation and bioaugmentation for remediation of soil contaminated with spent motor oil. Int J Environ Sci Technol 8(1):187-194. http://www.ijest.org/jufile?c2hvd1BERj00NjA= $\&$ ob $=$ cf5b89b0b166bafac7e52e2e6db55f53\&fileName=full_ text.pdf

Adams R (2004a) Chemical-biological stabilization of hydrocarboncontaminated soil and drilling cuttings in tropical México. Land Contam Reclam 12(4):349-361. http://epppublications.com/ Documents/12-04-05.pdf

Adams RH (2004b) Chemical-biological stabilization method for treatment of drilling cuttings and hydrocarbon contaminated soil. 11th international environmental petroleum conference. International environmental petroleum consortium, Albuquerque N.M. 11-15 Oct 2004. http://ipec.utulsa.edu/Conf2004/Papers/ adams.pdf

Adams RH (2008) Chemical-biological stabilization process for repairing soils and cuttings contaminated with oils and petroleum derivatives. US patent registry no. US 7,413,383 B2. US Patent and Trademark Office, Washington, DC http://www. patentgenius.com/patent/7413383.html

Adams RH, Guzmán-Osorio FJ (2008) Evaluation of land farming and chemico-biological stabilization for treatment of heavily contaminated sediments in a tropical environment. Int J Environ Sci Technol 5(2):169-178. http://www.ijest.org/jufile?c2hvd1 BERj0yMDU $=\& o b=82 d 2979 a 24 c d b 8 b 46 a f 8434 d 9584 \mathrm{e} 718 \&$ fileName=full_text.pdf

Adams Schroeder RH, Domínguez Rodríguez VI, Vinalay Carrillo L (2002) Evaluation of microbial respiration and ecotoxicity in contaminated soils representative of the petroleum producing region of southeastern Mexico. Terra Latinoamericana 20(3):253-265. http://redalyc.uaemex.mx/redalyc/pdf/573/573 20304.pdf

Adams RH, Alvarez RJA, Tinal OC, Guzman OFJ (2005) 12th international environmental petroleum conference. International environmental petroleum consortium, Houston, Texas 7-11 Nov 2005. http://ipec.utulsa.edu/Conf2005/Papers/Adams_Restoration_ of_Brine.pdf

Adams RH, Guzman-Osorio FJ, Alvarez-Rivera JA, DominguezRodriguez VI (2007) Long term fertility monitoring of soil treated by the chemical-biological stabilization method. 14th international environmental petroleum conference. International environmental petroleum consortium, Houston, Texas, 6-9 Nov 2007. http://ipec.utulsa.edu/Conf2007/Papers/Adams_34.pdf

Adams RH, Morales-Bautista CM, Torres-Torres JG (2011) Alternative method for establishing clean-up criteria based on API gravity. 18th annual international petroleum \& biofuels environmental conference. International Environmental petroleum consortium, Houston, Texas, 7-10 Nov 2007. http://ipec.utulsa. edu/Conf2011/2011agenda.html

Bakhtiari AMS (2003) Middle East oil production to peak within next decade. Oil Gas J 101(26):1-10. http://www.ogj.com/articles/print/ volume-101/issue-26/general-interest/middle-east-oil-productionto-peak-within-next-decade.html

Bilotta GS, Brazier RE, Haygarth PM (2007) The impacts of grazing animals on the quality of soils, vegetation, and surface waters in intensively managed grasslands. Adv Agron 94:237-280. http:// www.sciencedirect.com/science/article/pii/S0065211306940061

Energy Information Administration (EIA); statistical and analytical agency within the U.S. Department of Energy (2009) Annual energy review. World crude oil production, 1960-2009. http:// www.eia.doe.gov/aer/txt/ptb1105.html

Environmental Protection Agency (EPA) (1997) Test methods for evaluating solid waste: physical/chemical methods. Environmental protection agency, publication no. EPA 530/SW-846. http://www.epa.gov/osw/hazard/testmethods/sw846/online/

Escalante Espinosa E (2000) Estudio de ecotoxicidad de un suelo contaminado con hidrocarburos. Tesis Maestro en Biotecnología. Universidad Autónoma Metropolitana, México, DF. http:// tesiuami.izt.uam.mx/uam/aspuam/presentatesis.php?recno=10492 $\&$ docs=UAMI10492.PDF

Gómez Y, Paolini J (2006) Actividad microbiana en suelos de sabanas de los Llanos Orientales de Venezuela converitdas en pasturas. Int J Trop Biol 54(2):273-285. http://www.scielo.sa.cr/pdf/rbt/ v54n2/3819.pdf

Infante C (2001) Biorrestauración de áreas impactadas por crudo por medio de intebios ${ }^{\circledR}$ y biorize ${ }^{\circledR}$. INCI 26(10):504-507. ISSN 0378-1844. http://www.scielo.org.ve/scielo.php?script=sci_arttext \&pid=S0378-18442001001000014\&lng=es\&nrm=iso $>$

International Union of Soil Sciences (IUSS) (2006) World reference base for soil resources 2006. IUSS working group WRB. World soil resources reports no. 103. FAO, Rome. http://www.fao.org/ $\mathrm{nr} /$ land/pubs/wsoilrep/it/

Kross BC, Cherryholmes K (1993) Toxicity screening of sanitary landfill leachates: a comparative evaluation with Microtox analyses, chemical, and other toxicity screening methods. In: Richardson ML (ed) Ecotoxicology monitoring. VCH Publishers, Weinheim, Germany and New York City, pp 225-249. http://www.amazon.ca/Ecotoxicology-Monitoring-Mervyn- 
Richardson/dp/1560817364/ref=sr_1_1?s=books\&ie=UTF8 \&qid=1328559729\&sr $=1-1$

Mayo-López TM, Adams RH, Domínguez-Rodríguez VI, GuzmánOsorio FJ (2010) Organic amendment optimization for treatment of hydrocarbon contaminated soil using the chemical-biological stabilization process. Afr J Biotechnol 9(42):7079-7085. http:// academicjournals.org/AJB/PDF/pdf2010/18Oct/Mayo-Lópezetal. pdf

Neuhauser EF, Loehr RC, Malecki MR, Milligan DL, Durkin PR (1985) The toxicity of selected organic chemicals to the earthworm Eisenia foetida. J Environ Qual 14(3):383-388. http://soils.org/publications/jeq/abstracts/14/3/JEQ0140030383

Osorio NW, Casamitjana M (2011) Toma de muestras de suelos para evaluar la fertilidad del suelo. Suelos Ecuat 41(1):23-28. ISSN 0562-5351. https://sites.google.com/site/suelosecuatoriales/ descarga-de-articulos/volumen-41-2-1

Osuji LC, Ezebuiro PE (2006) Hydrocarbon contamination of a typical Mangrove floor in Niger Delta, Nigeria. Int J Environ Sci Technol 3(3):313-320. http://www.ijest.org/jufile?c2hvd1BE Rj0xMzM=\&ob=0e7a35d2bfbe82ffed97bd483f1649f5\&file Name=full_text.pdf

Sakari M, Zakaria MP, Che Abd RM, Lajis NH, Chandru K, Bahry PS, Shafiee MM, Anita S (2010) The history of petroleum pollution in Malaysia; Urgent Need for Integrated Prevention Approach. EnviromentAsia 3(special issue):131-142. http:// www.tshe.org/ea/pdf/vol3s\%20p131-142.pdf

Salanitro JP, Dorn PB, Huesemann MH, Moore KO, Rhodes IA, Rice Jackson LM, Vipond TE, Western MM, Wisniewski HL (1997) Crude oil hydrocarbon bioremediation and soil ecotoxicity assessment. Environ Sci Technol 31(6):1769-1776. http://pubs. acs.org/doi/pdfplus/10.1021/es960793i

Sánchez B, Ruíz M, Ríos MM (2005) Materia orgánica y actividad biológica en suelo en relación con la altitud, en la cuenca del río Maracay, estado Aragua. Agron Trop 55(4):507-534. http:// scielo.org.ve/pdf/at/v55n4/art04.pdf

Schulze ED (1967) Soil respiration of tropical vegetation types. Ecology 48(4):652-653. http://www.jstor.org/stable/1936509

SECOFI (1996) Norma Mexicana NMX-AA-112-1995-SCFI, Secretaria de Comercio y Fomento Industrial, Análisis de agua y sedimentoevaluación de toxicidad aguda con Photobacterium phosphoreum-Método de prueba, México, DF, Dirección General de Normas, 6 marzo

Secretaría de Medio Ambiente y Recursos Naturales (SEMARNAT) (1993) Norma oficial mexicana NOM-053-SEMARNAT-1993. Que establece el procedimiento para llevar a cabo la prueba de extracción para determinar los constituyentes que hacen a un residuo peligroso por su toxicidad al ambiente. Secretaría de Medio Ambiente y Recursos Naturales, México, DF, Diario Oficial de la Federación 22 de octubre de 1993. http://biblioteca. semarnat.gob.mx/janium/Documentos/Ciga/agenda/PPD02/ DO2283m.pdf

Secretaría de Medio Ambiente y Recursos Naturales (SEMARNAT) (2002) Norma oficial mexicana NOM-021-SEMARNAT-2000 que establece las especificaciones de fertilidad, salinidad y clasificación de suelos, estudio, muestreo y análisis. Diario Oficial de la Federación 23 de diciembre de 2002. http:// biblioteca.semarnat.gob.mx/janium/Documentos/Ciga/libros 2009/DO2280n.pdf

Secretaría de Medio Ambiente y Recursos Naturales (SEMARNAT) (2005) Norma oficial mexicana NOM-138-SEMARNAT-2003 Límites máximos permisibles de hidrocarburos en suelos y las especificaciones para su caracterización y remediación, México, DF, Diario Oficial de la Federación 29 de marzo de 2005. http://www.ordenjuridico.gob.mx/Federal/PE/APF/SEMARNAT/ Normas/Oficiales/209032005(1).pdf

Torres LGB, Climent M, Saquelares J, Bandala ER, Urquiza G, Iturbe R (2007) Characterization and treatability of a contaminated soil from an oil exploration zone. Int $\mathrm{J}$ Environ Sci Technol 4(3):311-322. http://www.ijest.org/jufile?c2hvd1BERj0yMjI= $\& o b=4029 a 53725 \mathrm{cb} 1169 \mathrm{ccc} 0 \mathrm{ac} 5 \mathrm{e} 34 \mathrm{ef93e} \&$ fileName=full_ text.pdf

Wang W, Guo J, Oikawa T (2007) Contribution of root to soil respiration and carbon balance in disturbed and undisturbed grassland communities, northeast China. J Biosci 32(2):375-384. http://www.springerlink.com/index/A6464LT412216257.pdf

Washington State Department of Ecology (WSDE) (1991) The model toxics control act cleanup regulation, Chapter 173-340 WAC. Amended February 2001. Olympia, Washington. http://www. ecy.wa.gov/biblio/wac173340.html

Yazdanparast F, Nouri A, Rabbani M (2004) Identification and determination of PAHs compounds in Anzali International Wetland. Int J Environ Sci Technol 1(3):215-219. http://www. ijest.org/jufile?c2hvd1BERj0yNQ==\&ob=e9f3d827ebffce9bbae d0d3ed592d278\&fileName=full_text.pdf

Yousefi Kebria D, Khodadadi A, Ganjidoust H, Badkoubi A, Amoozegar MA (2009) Isolation and characterization of a novel native Bacillus strain capable of degrading diesel fuel. Int $\mathbf{J}$ Environ Sci Technol 6(3):435-442. http://www.ijest.org/jufile? c2hvd1BERj0zMzc=\&ob=ce4469d7b14bd1451361901ae37f4f7 d\&fileName=full_text.pdf 